\title{
A BRAZILIAN MUNICIPAL BOND MARKET: THEORY, REPRESSION AND PROSPECTS
}

Kurt von Mettenheim kurt.mettenheim@fgv.br

Professor da Escola de Administração de Empresas de São Paulo, Fundação Getulio Vargas - São Paulo - SP, Brazil

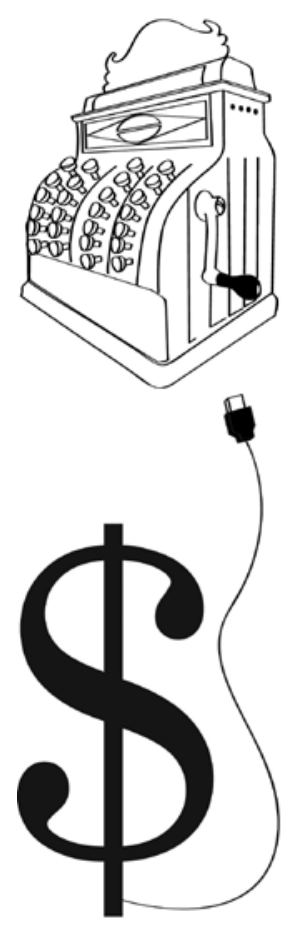

BRAZIL, 2000), the imposition of fiscal responsibility legislation and hard won stability during the 1990 s and 2000s (AFFONSO, 2003). Today, the repression of municipal finance is perhaps the single most important unrecognized cause of slow growth and disappointing politics and local public management in Brazil.

This paper presents three diagnoses and a proposal. The first diagnosis is that municipal finance underdevelopment is the most critical bottleneck for Brazilian economic and political development. The second diagnosis is that steps toward a Brazilian municipal bond market are politically and economically viable, timely and necessary to reap the rewards of reforms and modernization that have won investment grade ratings for sovereign and corporate issues. The third diagnosis is that municipal bond markets abroad provide sound guidelines and clear benchmarks to free more effective local finance and design a Brazilian market. The paper concludes with a proposed timeline for mobilizing 
interested parties and the design and implementation of a Brazilian Municipal Bond Market 2012-16.

\section{MUNICIPAL FINANCE UNDERDEVELOPMENT IS THE ACHILLES HEEL OF BRAZIL}

Despite all the advances of economic reforms, record capitalization of the BM\&F-Bovespa market and creation of world-class financial regulation, the public sector and, especially, municipal finance have nonetheless been left behind. If recentralization (EATON; DICKOVICK, 2004) and fiscal dominance (BLANCHARD, 2004) were mantras in the 1990 s, financial repression of municipalities and decentralization must be mantras for the 2010s. Military government and protracted transition did indeed leave state and municipal governments open to capture by traditional elites (HAGOPIAN, 2007). However, under constitutional government from1946-64, municipalities retained 10 percent of public revenue and were free to finance accordingly without requirements set by federal or state governments. Looking further back, the municipality of Santos financed construction of canals in the 1920s by sale of 30 year bonds in London at 5 percent interest rates (MAURO et al, 2006). Despite positive precedents from abroad and the past in Brazil, biases against public finance on the left and right have led to overemphasis on the private sector and repressed innovative local public finance management.

Figure 1 illustrates the structural trend downward in growth in Brazil that accompanied increases in private investment and private sector capital formation after the first oil shock in 1973. Instead, a clear correlation obtains between the decline of GDP growth and falling levels of public savings and public capital formation after the late 1970s. Statistical analysis is beyond the scope of this paper and many other factors for reduced growth are surely important (RODRICK, 2003; BRESSER-PEREIRA e GALA, 2007). However, the data on private, public and foreign savings and GDP growth 1948-2000 introduce our argument. The public sector has been left behind in Brazil. Overcoming constraints to growth requires new ideas about public sector finance.

Capital formation displays the same trend, as can be seen on Figure 2. Since decline of public capital formation caused by the crisis of the developmental state in the 1980s, increases in private capital formation have been unable to produce higher levels of growth. Other barriers to growth certainly matter. However, municipal finance development provides an untapped alternative policy agenda for modernization of the public sector, increasing growth, improving public management and encouraging the emergence of a new generation of market savvy political leaders in local government.

The causes and consequences of slow Brazilian growth have been widely debated since fiscal and debt crises pervaded the end of military rule and transition to democracy in the 1980s. However, one observation seems clear. Brazil will be unable to sustain higher growth and financial deepening toward AAA ratings without modernization of municipal finance, where provision of most public services takes place and where participation of the private sector and public management modernization are most urgent. Underdevelopment of local public finance hamstrings growth and reinforces administrative centralization in state capitals and Brasilia, reproducing ineffective top down, command and control strategies of public management, increasing the cost of capital, decreasing the efficiency of the public sector and leaving private and foreign investment unable to improve local infrastructure. Since the 1990s, price stability, privatizations, liberalization and modernization of regulatory authorities have transformed the BMF-Bovespa into a world class stock market. However, the concentration of fixed income instruments in a very few number of bonds from federal and select state government entities limits portfolio and risk diversification, runs counter to public finance paradigms and best practices abroad, and reproduces the financial repression of municipalities. The rigidity of top down mandatory transfers and the inability of local governments to tap capital markets reproduce inefficiencies and throttle innovation. Modernization of municipal credit and local government bond issues do indeed present risks such as crony credit and market bubbles. However, with sound regulation, transparent market valuation and controls, the work of credit rating agencies, banks and risk analysts, independent advisory services and the entry of new actors such as bond banks and insurance companies, as a whole, are capable of providing powerful incentives and premiums for innovative municipal finance management while vetoing unsustainable projects. Corruption 
will not disappear overnight. But municipal financial development provides an alternative to the current practice of exclusive reliance on costly prosecution of abuses by public prosecutors, lawyers, the judiciary and police forces. Municipal credit and bond ratings would function differently by offering premiums instead of punishment at much less cost to public authorities.

\section{A Brazilian muni market: necessary, timely and viable}

Reforms in Brazil since the 1990s provide a large window of opportunity to initiate a virtual cycle of municipal finance development with broad political support. Price stability (1994), liberalization of banking (1995), adoption of the policy tripod of inflation targeting, fiscal control and flexible foreign exchange (1999), capitalization of financial markets, mutual funds and fixed income instruments, and achievement of investment grade ratings for sovereign issues and companies; Brazil now retains the necessary ingredients to deepen municipal credit operations

\section{Figure 1 - Private, public and foreign savings \& GDP growth, 1948-2009}
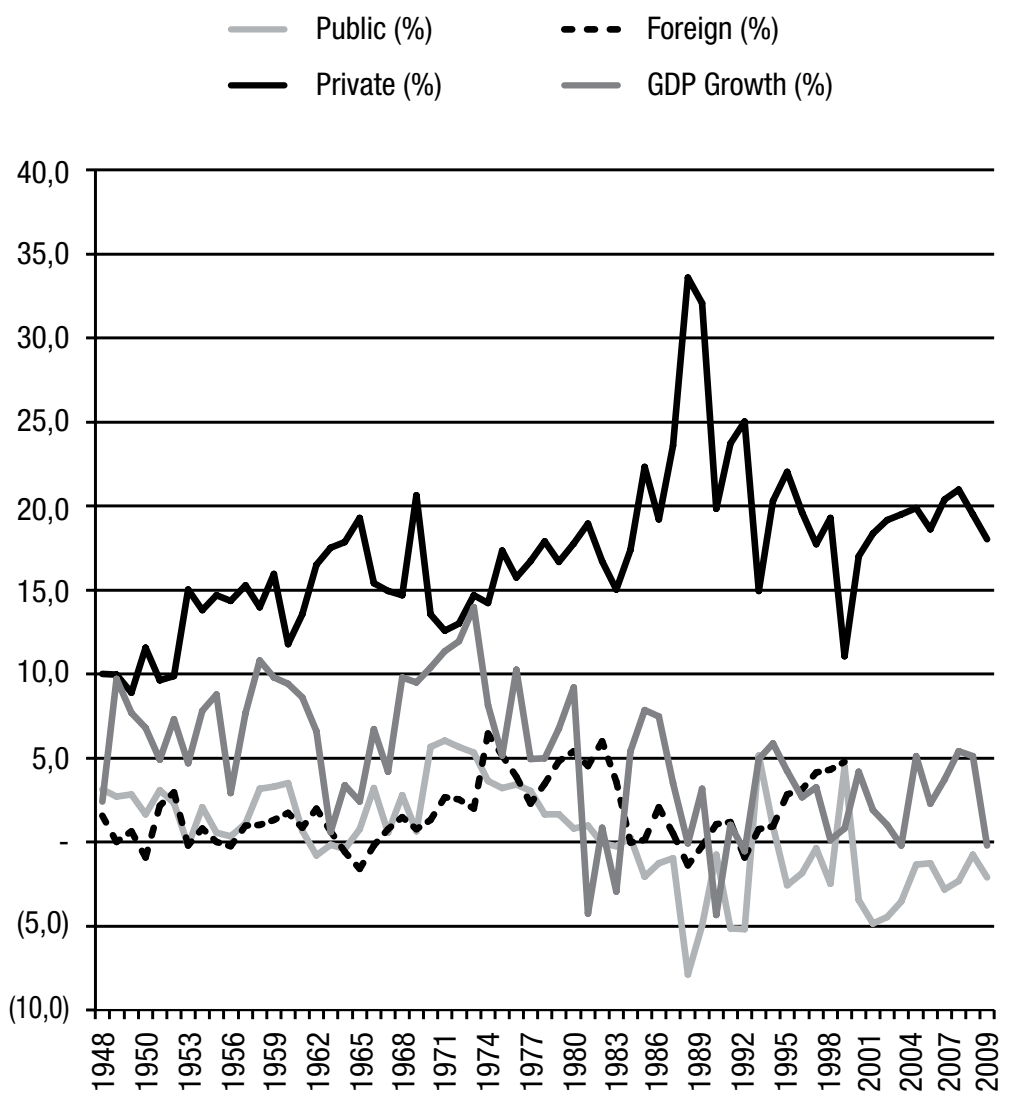

Source: IBGE. Available on www.ibge.gov.br/seculoxx/economia/contas_nacionais/contas_nacionais.shtm Note: The new IBGE National Accounts System omits foreign savings after 1999.

and create a municipal bond market. Somewhat paradoxically, because of repressed demand, high margins and the definition of new credit procedures for municipalities in place since 2006, municipal finance is an easy, almost self-starter. Brazilian banks, regulatory authorities and financial markets have achieved global standards in management, transparency, supervision, reporting and government-market relations. The modernization of municipal credit practices and the creation of a municipal bond market are fundamental to sustain financial development, increase the pace and quality of economic growth and deepen market confidence.

Local governments required adjustment to the end of inertial inflation in 1994 (like banks, firms, and other agents in the economy). Price stability ended incentives to acquire debt and delay payment, but also left municipalities facing new fiscal realities. Fiscal reforms, spending reductions, administrative modernization and privatizations culminated in rigid fiscal responsibility legislation in 2000. Packaging local debts by the federal government from 1997 through 2000-1 was initially favorable to municipalities but has become extremely onerous 15 years later because of high interest rates (CARVALHO et al, 2012; OLENSCKI, 2008). Fiscal responsibility legislation dramatically improved local government accounting, budgeting and reporting standards during the 2000s. However, today, burdensome debt and excessive fiscal control now reproduce the financial underdevelopment of municipalities while reforms make change possible. Regulations and practices developed during 
the 2000s such as pluri-annual planning procedures, annual budget laws and modernization of the independent registry for public sector credit operations (Sistema de Registro de Operações de Crédito com o Setor Público, CADIP) have improved municipal management and set the framework for financial development municipal governance. Moreover, Senate Resolution 43/2001 freed and Treasury and the Finance Ministry (in August 2006) introduced a new process for Central Bank,
Senate and Treasury approval of new municipal credits. Since 2006, a 'Manual de Instrução de Pleitos de Crédito' (Credit Request Instruction Manual) provides clear procedures and application forms online for proposal of credit operations. Municipalities currently may thereby contract loans from banks in Brazil or abroad up to 120 percent of liquid receipts (STN, 2006). In sum, reforms and this new regulatory framework have set clear procedures for deepening of municipal credit and make
Figure 2 - Private and public capital formation

\& GDP growth, 1948-2009

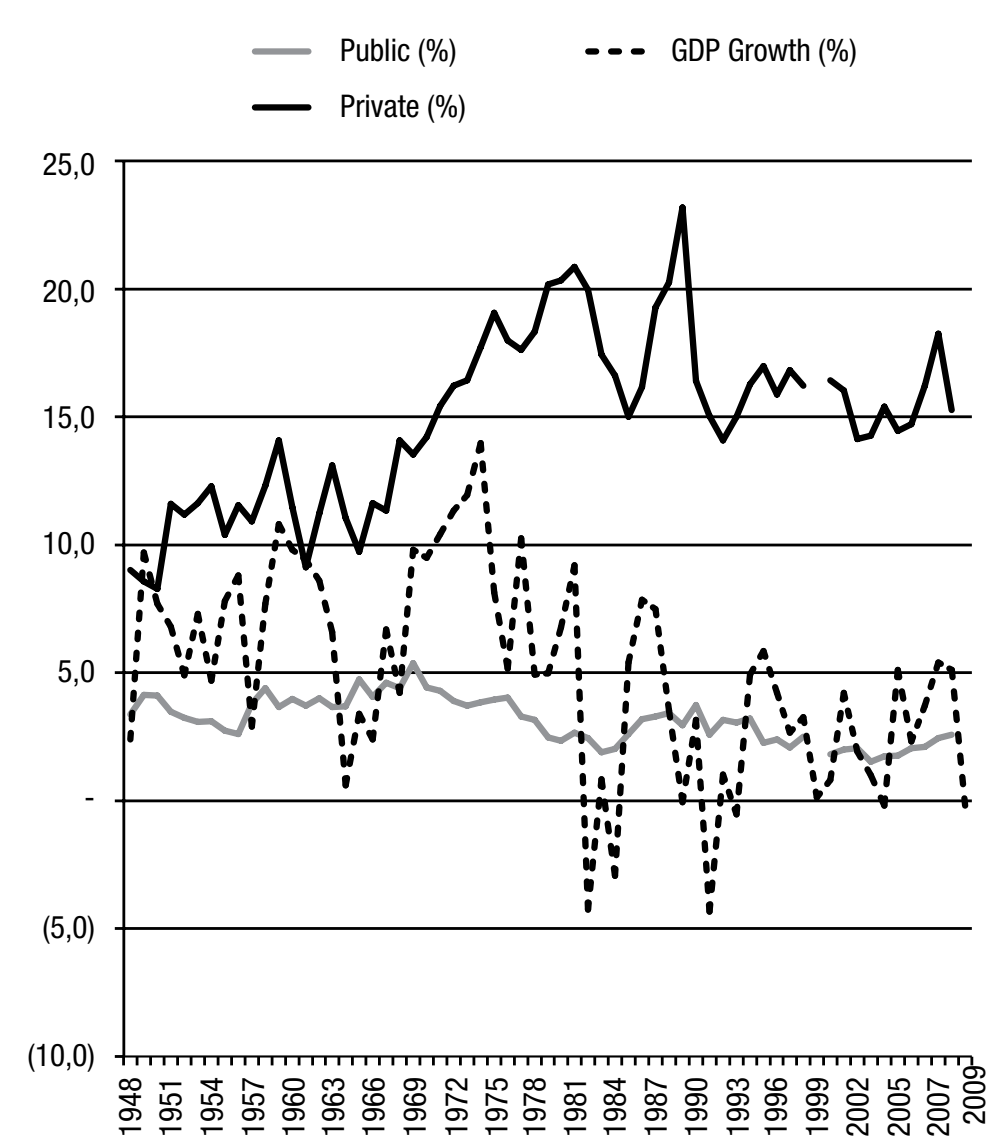

Source: IBGE. Available on: www.ibge.gov.br/seculoxx/economia/contas_nacionais/contas_nacionais.shtm

Note: Missing data due to change in IBGE national accounts system.

possible the next steps of financial modernization and launch of a Brazilian municipal bond market.

However, underdevelopment is still marked. Only 18 municipalities in Brazil had loan contracts in 2000 outside the consolidation of debts by federal government. Since then, public banks have begun, in very limited ways, to finance municipalities. Meanwhile, local government officials have struggled to work with limited tax capacity, rigid federal government transfers, complex credit regulations and budget controls, inability to customize credit operations and top down command and control governance from Brasilia and state capitals (OLENSCKI, 2008; GASPARINI; MIRANDA, 2006). Table 1 reports the shares of tax receipts and government funds received by the three levels of government in Brazil (federal, state, municipal) from 2006-2010. The municipal share of tax receipts increased from 2.7 percent (in 1988, not in table) to 7.1 percent by 2010. Meanwhile, municipal share of government funds increased from 13.8 percent (in 1988, not in table) to 16.8 percent by 2010 . This indicates the current misalignment between tax authority and municipal budgets that leave local finance managers prisoner to requirements set in Brasilia mandating spending on health (12 percent), education (13 percent) and other programs often summing to 100 percent of local government budgets (ALENCAR; GOBETTI, 2008).

The large number $(5,564)$ and wide variety of municipalities in Brazil make the problem of rigidity in mandatory federal transfers and funds worse. However, this also suggests opportunities for 
credit and finance operations. Big cities notoriously have big financial problems, in Brazil and abroad. São Paulo city alone was responsible for two thirds of the total value of municipal debt packaged in 2001, originating largely in shady operations from judicial deposits under MalufPitta administrations (OLENSCKI, 2008). Municipal bankruptcies and debt renegotiations in the US also typically involve large cities such as New York in the 1970s and Orange County, California in the 1990s. However, the large number of midsized municipalities in Brazil with independent tax bases provides sufficient scale to engender local credit and finance development by spreading risk for investors and providing many opportunities to diffuse innovative best practices of local finance officers through benchmark operations (See Table 2).

Federal transfers may straightjacket local governments. However, annual reporting to Treasury required by fiscal responsibility laws and federal fund transfers helped modernize municipal management. Municipalities currently manage federal fund transfers in health (Sistema Único de Saude, SUS), social assistance (Sistema Único de Assistência Social, SUAS), education (Fundo de Manutenção e Desenvolvimento do Ensino Fundamental, Fundef), agrarian reform (Fundo de Terras e da Reforma Agrária), poverty elimination (Fundo de Combate e Erradicação da Pobreza), participation funds (Fundos de Participação dos Estados e Municípios, FPM) (GASPARINI; MIRANDA, 2006), social development (Fundo de Desenvolvimento Social, FDS) and basic income (Programa de Garantia de Renda Mínima).

Municipalities have also explored new arrangements designed to tap private sector participation in local government through concessions, privatizations, sale of judicial deposits, publicprivate-partnerships (PPPs), administrative reform and securitization of receivables. However, these arrangements have had very limited success in large part because innovation has been stifled by the burden of managing federal and state transfers and mandatory programs. The vast majority of municipalities have thus not secured credit operations and very few have capitalized policies by contracting credit up to the limit of 120 percent of liquid receipts permitted under current regulations. Current regulations and procedures thereby provide a compelling point of departure for the modernization of municipal finance.

In sum, Brazilian municipalities have recovered from capture under military rule and delayed transition to democracy. Municipalities began to modernize under central government control in the 1990s and adapted to rigid fiscal responsibility legislation and detailed budget reporting requirements during the 2000 s to manage a wide variety of funds and transfers mandated by federal government. Meanwhile, the value of municipal debt packaged by the federal government in 2001 has exploded because of astronomic interest rates. A more realistic renegotiation of the 2001 package is therefore another necessary step toward local public finance development (GIAMBIAGI et al, 2008).

\section{NEW PUBLIC FINANCE MANAGEMENT}

Municipal credit operations and creation of a municipal bond market would reinforce the transition currently underway in Brazil away from old public management practices that keep capital costly, slow economic growth and cause conflicts over central

Table 1 - Taxes and funds by level of government, 2006-2010

\begin{tabular}{|c|c|c|c|c|c|c|c|}
\hline & \multicolumn{3}{|c|}{ \% Tax Receipts } & \multicolumn{3}{c|}{ \% Government Funds } & \\
\hline & Federal & States & Municipal & Federal & States & Municipal & Total, R\$ billion \\
\hline 2006 & 62.5 & 31.0 & 6.4 & 55.5 & 27.4 & 16.9 & 844.2 \\
\hline 2007 & 63.2 & 30.2 & 6.5 & 56.5 & 26.7 & 16.7 & 970.3 \\
\hline 2008 & 62.3 & 31.1 & 6.5 & 56.3 & 26.8 & 16.7 & $1,111.1$ \\
\hline 2009 & 60.6 & 32.3 & 7.0 & 54.4 & 27.5 & 18.0 & $1,148.3$ \\
\hline 2010 & 60.2 & 32.6 & 7.1 & 57.0 & 26.1 & 16.8 & $1,138,4$ \\
\hline
\end{tabular}

Source: Treasury Secretary. 
and state government transfers to municipalities. Municipal finance development and a Brazilian municipal bond market would accelerate the adoption of new public management techniques (SANO e ABRUCIO, 2008), bring greater transparency, financial advocacy, education and training and public-private collaboration and reinforce a virtuous cycle of public sector modernization.

Perhaps most importantly, local public finance would help change local politics in Brazil along the lines indicated by Abrams in the epigram of this article. The modernization of credit and finance in local governments would free local finance secretaries to innovate and receive recognition for benchmark operations from markets by winning financial premiums and better ratings. Credit and finance provide cheaper means and powerful incentives in comparison to the costly, top-down, command and control methods of hierarchy and bureaucratic management that currently involves police, prosecutors, lawyers, judges in the interest of punishing municipal managers and imposing fiscal responsibility legislation. Frant (1996) described this as a difference between low-powered and highpowered incentives in the public sector. The high-powered incentives of bank loans and municipal bond sales provide promising alternatives to the shortcomings of traditional public sector hierarchies, the high cost of command and control bureaucratic management techniques, the complexities of legal contests in courts, and political control over policy currently enforced on Brazilian municipalities (WILLIAMSON, 1994).

Municipal finance development does not mean that anything goes. Core principles such as debt affordability, competitive sale, due diligence and disclosure, investor outreach, informed decision making by municipal finance managers, and services provided by independent financial advisory to avert conflict of interest are required to ensure prudent municipal debt management and avert moral hazard. Debt affordability requires the creation of independent advisory

\section{Table 2 - Municipal size and tax capacity}

\begin{tabular}{|c|c|c|c|}
\hline $\mathbf{0 0 0}$ residents & Taxes & Transfers & Other \\
\hline$<2$ & 1.8 & 93.4 & 4.8 \\
\hline $2-5$ & 2.6 & 92.5 & 4.8 \\
\hline $5-10$ & 4.1 & 89.9 & 5.9 \\
\hline $10-20$ & 4.8 & 89.4 & 6.0 \\
\hline $20-50$ & 7.4 & 83.4 & 9.1 \\
\hline $50-100$ & 12.5 & 75.4 & 12.0 \\
\hline $100-200$ & 14.3 & 69.2 & 16.4 \\
\hline $200-500$ & 20.9 & 62.7 & 16.3 \\
\hline $500-1000$ & 20.5 & 62.1 & 17.2 \\
\hline $1000-5000$ & 26.9 & 51.6 & 21.4 \\
\hline$>5000$ & 39.8 & 40.7 & 19.5 \\
\hline
\end{tabular}

Source: IBAM, 'Banco de Dados Municipais,' 2007

committees charged with writing annual reports on municipal budgets that publish calculation of debt serviceability scenarios. The principle of competitive sale is essential to ensure proper sale of bonds at market prices that may avert murky deals between local government officials, banks, investors or consortia. This ensures transparency and the lowest cost of finance for local governments. Due diligence and full disclosure require timely publication of the financial accounts of municipal assets and liabilities, permitting accurate credit ratings and pricing of bond values. Brazilian municipalities routinely report this type of information thanks to more than a decade of fiscal responsibility legislation and planning and budget requirements. Investor outreach implies communication and investor relation road trips to promote projects, loans and municipal bond issues. Informed decision making and independent financial advisory imply the representation of municipalities by financial specialists not linked to banks or investors to ensure against conflicts of interest in the issue of municipal bonds or signing of loan contracts.

In sum, new public finance management seeks to harness the high powered incentives of markets to reinforce decentralization, democratization, transparency and accountability. Credit operations and bond issues would capitalize the public sector through issuer driven investor outreach and introduce a range of new services such as cost-benefit analysis, debt affordability analysis, capital planning, cash management, debt and finance policy analysis, use of new technologies of information 
and communication and municipal finance education workshops. So, how to get there from here?

\section{RECOMMENDATIONS FROM MUNICIPAL BOND MARKETS ABROAD}

Municipal bond markets abroad provide a wealth of references for Brazil. The US experience and case studies and comparative analyses of experiences of financial development of local governments in Eastern Europe and other emerging countries illustrate how Brazilian cities can explore opportunities.

\section{United States}

After municipal bonds contributed to and suffered from periodic crises under free banking in the US (1837, 1873, 1893), restrictions were imposed (STARNER, 1961). However, US sub-national debt nonetheless grew from 2.1-14.9 billion dollars 1902-27 before downturns during two world wars and depression in the 1930s. After 1945, local public finance helped drive sustained growth, with 'innovative diffusion' of best practices and benchmark bond issues increasing the capitalization of local government entities from 66.0 billion dollars in 1960 (subnational debt) to 399.4 billion dollars of municipal bonds by 1980 (KATZMAN, 1980). Meanwhile, the problems experienced during the 19th century disappeared. Defaults on municipal bonds 1941-90 remained below 1.1 percent. The municipal bond market during this period became one of the safest markets for investors. The 2008 crisis disrupted the liquidity of secondary markets for US municipal bonds during 2009 (FSOC, 2011:38). And the economic downturn produced by financial crisis has also placed stress on local government accounts and required adjustment (BERNANKE, 2011). However, municipal bonds recovered in 2009 to near traditional spreads (80 points) over treasury bills to remain a safe haven for investors and inexpensive source of finance for local government entities. In sum, the US muni market has provided safe and sound investments for decades (HILDRETH; ZORN, 2005).

To illustrate the stability and safety of the US municipal bond markets, Table 3 reports the capitalization of major types of bonds in US markets 19802011. Municipal bonds (column 1) retained a sustainable growth pattern 1980-2011 (from 0.4-3.7 trillion US\$) averting both the bubble and bursting of bonds such as mortgage backed securities (0.18.4 trillion US\$). The trajectory of municipal bonds also stands in contrast to the increase of Treasury issues from anti-crisis measures since 2008 to over 9.9 trillion US\$. Moreover, despite alarm and pessimism during the adjustment of local government budgets to the US crisis since 2008, no major default of municipal bonds has been reported.

Levine (2009) suggests that the following characteristics of the US municipal bond market are most relevant for municipal finance development in Brazil: Subsidies from US federal tax benefits to investors; clear and shared accounting standards set by the Governmental Accounting Standards Board (GASB); a longstanding record of repayment; a decentralized tax system; legal clarity about priority liens for debt; liquid secondary market trading; oversight by a variety of regulatory agencies and authorities; and informed independent credit ratings of municipal governments and entities. The historical development and current structure of the US municipal bond market thereby provide a series of guidelines for municipal finance development in Brazil.

\section{Eastern Europe}

Experiences with issue of municipal bonds in Eastern Europe also suggest that clear limits on leverage, guidelines for prudent debt loads and conservative payout schedules, minimum enforceable disclosure standards (embodied in the US by SEC 15c2-12), use of annual amortization instead of balloon structuring, clear contracts for liens and recourse in case of non-payment for investors, establishment of transparent accounting presentation, and great care with initial operations to ensure success and provide benchmarks to accelerate diffusion are all critical lessons for Brazil. Eastern European experiences also suggest the importance of educating rating agencies, investors, banks, political leadership and the financial press to create advocacy networks that may become municipal bond communities. While small municipalities may not retain sufficient scale or experience for municipal bond issues, the pooling of credits and municipal consortia nonetheless provide alternative means for local public finance. Finally, municipal finance 
development in Eastern Europe counsels beginning simple and small (by avoiding complex bonds or structures) and that enhancing the protection of investors by pledging revenue are critical.

\section{Emerging countries}

Comparative studies of municipal bond development in emerging and developing countries also emphasize the importance of policy and tax devolution, the financial autonomy of local governments, the need for promotion of public finance modernization and the critical role of legal-regulatory frameworks.
Martell and Guess (2005) report successful launches in South Africa, Poland, the Philippines and Mexico. Olenscki (2008:6388) argues that Mexico was able to deepen municipal credit operations despite a shallow local tax base and many similarities with Brazil. Allen et al (2012) emphasize the importance of 'policy financial bonds' in China. These bonds are issued by policy banks and held by Treasury, but invested locally similar to bonds in the US. International development banks have also reviewed experiences with projects designed to deepen local public finance (PETERSON, 1997; 2003).

\section{RISKS AND MECHANISMS OF CONTROL}

Although further comparative analysis is required, these observations help clarify the challenges for municipal finance development in Brazil. The shallow tax base and rigidity of municipal budgets indicate the need for policy devolution. Credit to municipalities in Brazil is limited by regulations that cap loans at 120 percent of liquid receipts and debt service at 11.5 of liquid receipts. However, as noted, this provides opportunities because few Brazilian municipalities use the financial space opened by rules established in 2006.

\section{Table 3 - US Bonds outstanding, 1980-2011, US\$billion}

\begin{tabular}{|c|c|c|c|c|c|c|c|c|}
\hline & Municipal 7 & Treasury 1,6 & $\begin{array}{c}\text { Mortgage } \\
\text { Related 2,6 }\end{array}$ & Corporate & $\begin{array}{c}\text { Federal } \\
\text { Agency 5,6 }\end{array}$ & $\begin{array}{c}\text { Money } \\
\text { Markets } 3\end{array}$ & $\begin{array}{c}\text { Asset } \\
\text { Backed 4,6 }\end{array}$ & Total \\
\hline 1980 & 399,4 & 623,2 & 110,8 & 458,6 & 164,3 & 780,0 & & 2536,4 \\
\hline 1985 & 859,5 & 1437,7 & 396,7 & 776,6 & 261,0 & 847,0 & 1,2 & 4579,7 \\
\hline 1990 & 1178,6 & 2195,8 & 1278,1 & 1350,3 & 421,5 & 1156,8 & 75,8 & 7656,9 \\
\hline 1995 & 1268,2 & 3307,2 & 2352,7 & 1950,6 & 924,0 & 1177,3 & 257,0 & 11237,0 \\
\hline 2000 & 1480,7 & 2951,9 & 3565,8 & 3358,4 & 1853,7 & 2662,6 & 1085,0 & 16958,1 \\
\hline 2001 & 1603,4 & 2967,5 & 4127,4 & 3836,4 & 2157,4 & 2587,2 & 1230,3 & 18509,7 \\
\hline 2002 & 1762,9 & 3204,9 & 4686,4 & 4132,8 & 2377,7 & 2545,7 & 1381,5 & 20091,9 \\
\hline 2003 & 1900,4 & 3574,9 & 5238,6 & 4486,5 & 2626,2 & 2519,8 & 1507,6 & 21854,0 \\
\hline 2004 & 2850,3 & 3943,6 & 5390,5 & 4801,6 & 2700,6 & 2904,2 & 1814,0 & 24404,8 \\
\hline 2005 & 3044,2 & 4165,9 & 6161,8 & 4964,7 & 2616,0 & 3433,7 & 2111,0 & 26497,3 \\
\hline 2006 & 3212,4 & 4322,9 & 7085,6 & 5344,2 & 2634,0 & 4008,8 & 2700,6 & 29308,5 \\
\hline 2007 & 3448,0 & 4516,7 & 8161,1 & 5947,3 & 2906,2 & 4170,8 & 2946,4 & 32096,5 \\
\hline 2008 & 3543,4 & 5774,2 & 8396,1 & 6198,6 & 3210,6 & 3790,9 & 2600,9 & 33514,7 \\
\hline 2009 & 3698,0 & 7249,8 & 8506,9 & 6862,7 & 2727,5 & 3127,2 & 2326,9 & 34499,0 \\
\hline 2010 & 3794,5 & 8853,0 & 8515,8 & 7511,9 & 2538,8 & 2866,5 & 2034,5 & 36115,0 \\
\hline 2011 & 3743,3 & 9928,4 & 8440,0 & 7790,7 & 2316,6 & 2572,0 & 1815,4 & 36606,5 \\
\hline
\end{tabular}

1 Interest bearing marketable public debt.

2 Includes GNMA, FNMA, and FHLMC mortgage-backed securities and CMOs, and CMBS, and private-label MBS/CMOs,

3 Includes commercial paper, bankers acceptances, and large time deposits.

4 Includes auto, credit card, home equity, manufacturing, student loans and other; CDOs of ABS are included

5 Due to FAS 166/167 changes, the GSE debt category in the Federal Reserve is no longer our source for agency debt going forward from Q1 2010.

Contains agency debt of Fannie Mae, Freddie Mac, Farmer Mac, FHLB, the Farm Credit System, and federal budget agencies (e.g., TVA)

6 See SIFMA statistical explanations

7 Muncipal securities restated from 2004 onward and revised upward by about $\$ 840$ billion.

Source: SIFMA, 2012 
Comparative studies of municipal bonds in developing and emerging countries also emphasize that municipal credit and bonds should be priced by risk and placed on markets by private parties as underwriters or lenders (MARTELL; GUESS, 2006; BAHL; WALLACE, 2005; PETERSON, 1997). This requires risk assessment by financial institutions, banks, insurance companies, pension funds and securities firms. Municipal credit and bond sales also have proven critical for bringing greater clarity to the costs and benefits of alternative policies and subsidies. BNDES loans at lower interest rates may repress private finance to local governments. However, higher interest rates outside BNDES operations may encourage benchmark credit and bond issues (thereby attracting interest on the part of other banks and financial institutions). Moreover, convergence of SELIC (Sistema Especial de Liquidação e de Custódia, Special System of Liquidation and Custody) benchmark overnight interest rates set by government monetary authorities toward BNDES interest rates (Taxa de Juros de Longo Prazo, Long-Term Interest Rates, TJLP) also make private sector operations increasingly more viable.

Studies of municipal bond development (OLENSCKI, 2008; BAHL; WALLACE, 2005) abroad also emphasize the importance of local accounting systems that support asset management techniques and regular reports to permit comparison of planned and actual expenditures as well as to better track budgets and debt schedules. Again, some smaller municipalities remain behind fiscal and budgetary modernization. However, for the vast majority of municipalities, fiscal responsibility reports, pluriannual planning and annual budget laws now provide rich and accurate information sufficient for informed analysis of expenditures and debt. Reforms thus permit the evaluation of municipal projects according to economic criteria and the development of capital programming and budget procedures through costbenefit analysis and present value estimates.

\section{POLITICAL DEVELOPMENT}

Modernization of local public finance is also fundamental for political development. During the last decade, consensus has emerged that negotiation of multiparty coalitions at federal, state and local levels is perhaps the most critical problem for governance in Brazil. The underdevelopment of local public finance transforms coalition formation and budget politics into zero-sum disputes, often involving use of amendments to steer funds toward preferential projects. The short time horizons of disputes over annual budgets lines imposed by fiscal responsibility legislation also reinforces the zerosum character of conflicts between legislatures and executives. Lowering the stakes increases the irresponsibility of local public management.

Deepening of municipal credit and finance presents the prospect of more positive sum collaboration and high-powered incentives based on access to capital markets and the private sector. New public finance management offers an alternative to command and control strategies, costly bureaucratic review and expensive prosecution through accounting courts and the judiciary. Credit and finance use market contracts as powerful incentives and credit ratings as premiums to reduce the transaction costs of municipal management. Benchmark credits and municipal bond ratings would build on a decade of reporting to Treasury required by fiscal responsibility legislation. Instead of being "placed on a shelf out of the way' as described by Adams in the epigram to this article, municipal finance officers in Brazil would be free to innovate and gain recognition from markets, fellow politicians and voters. This modernization of local public finance and the deepening of credit and bond markets were critical for reducing corruption in US municipal governments. We argue that it may be so in Brazil also.

\section{Proposal: Brazilian Municipal bond market}

Recognition is now widespread that Brazil has introduced a series of successful economic and financial reforms and created world class regulatory frameworks, institutions and markets in banking and finance. Nonetheless, repression of local finance has made Brazil miss opportunities to direct capital movements toward public sector modernization and further increase the confidence of investors. The deepening of local public credit and taking steps toward a municipal bond market would tap recent reforms and free local finance officers to innovate. Fortunately, the record high interest rates of Brazil appear to be converging toward more viable international standards. 
The timing for municipal finance could not be better. The current still very high interest rates of Brazil imply large marginal returns for startup and benchmark credit operations. We estimate the market for municipal credit within current caps of 120 percent liquid receipts and 11.5 percent of debt obligations at over six billion reals. Financial space therefore exists to increase the transparency, accountability, decentralization and modernization of the public sector at its most critical point - in the 5,564 local governments across Brazil.

This would help reverse the brain drain of talented managers to the private sector, increase the capacity of banks to deal with public finance and deepen credit and capital markets in Brazil. Municipal bonds are the missing piece to crown development of BM\&F-Bovespa fixed income markets. This requires change. And while many challenges exist, it should be remembered that innovative credit and finance can quickly diffuse through relational finance management and pre-sale and post-sale events for education and training. This, in turn, would lead to additional loans on better terms that would further reduce the cost of capital for municipalities. Local finance modernization would also contribute to further improvement of Brazilian sovereign and corporate risk ratings.

The challenges and timeline for overcoming the separation of local governments from capital markets are summarized in Figure 3. This figure represents paths for municipal finance development based on experiences in other developing and emerging countries. Changes to the legal and regulatory framework of financial markets are indicated by 'a' arrows. Changes at government financial intermediaries are indicated by ' $b$ ' arrows. Changes in municipal finance management are indicated by 'c' arrows. Brazil currently remains in the first column on the left, where local governments rely almost exclusively on central government transfers, direct grants or lending from federal government banks. The second column indicates the role of government intermediaries that may bring capital markets and investors together with subnational governments to regulate and mobilize credit and finance to municipalities. The third column represents the mature market for municipal bonds that permits the removal of direct central government control and intermediation by public programs from municipal finance. The timeline below the figure represents how mobilization of municipalities through representative associations, modernization of bank divisions responsible for public sector finance, removal of constraints in the 2001 debt pact, revision of CVM and BOVESPA regulations, and education and training may reverse decades of bias against municipal finance management during 2013-16.

\section{CONCLUSION}

\section{A Brazilian Municipal Bond} Market is the missing ingredient for

\section{Figure 3 - Challenges for municipal finance development}

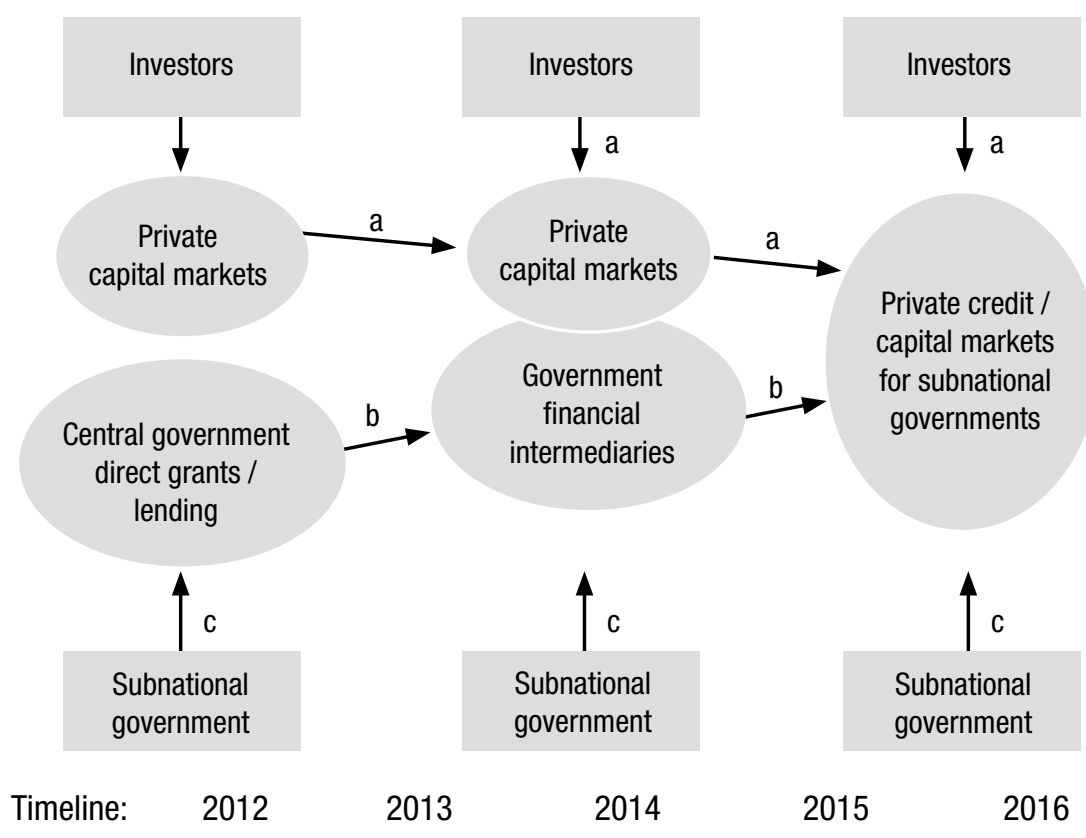


modernization of local government, political development and financial deepening. The 2008 financial crisis has led to reassessment of private sector biases and reflection on the excesses of deregulation. However, crisis in the US has also proved once again the solidity of municipal bonds and their importance for long term finance in many advanced economies. This article points to an anomaly and presents a proposal. The anomaly is that, despite profound advances in Brazil during the last decades, perceptions of fiscal dominance and repression of local public finance continue to reproduce economic and political underdevelopment. Fiscal controls were indeed necessary to secure adjustment to price stability in the 1990s. However, administrative centralization and fiscal control have impeded modernization of local government finance, slowed growth and stifled more dynamic political leadership at the local level. The importance of municipal bonds and credit abroad suggests that financial deepening and political and economic development in Brazil will fail to advance without rethinking local finance. The history of municipal finance in mature markets and recent efforts abroad to deepen local government finance in emerging, developing and transition economies suggest that, like past periods in Brazilian history, municipalities need access capital markets to remove bottlenecks and address legacies of underdevelopment. The proposal is to mobilize interested parties to spread best the best practices of local credit operations and new public finance management to pave the way for a municipal bond market in Brazil.

\section{NOTE OF APPRECIATION}

The author would like to thank Jeffrey Leifer, Paulo Arvate, Alkimar Moura, Antonio Olenscki and the participants in the "New Public Finance Management" workshop (2006); Norberto Torres, Luis Antonio Pazos and the participants in the "Novas Oportunidades para Financiamento Municipal" workshop (2007), and Eduardo Stranz, Steve Levine, Francisco Vignoli, Alkimar Moura, Otávio Yazbek, Fernando Zilvetti and participants of the "Municipal Finance Development" seminar (2009), for their comments and suggestions.

\section{REFERENCES}

ADAMS, H. C. Public Debt: an Essay in the Science of Finance. New York: D. Appleton Century, 1890.

AFFONSO, R. B. A. O federalismo e as teorias hegemônicas da economia do setor público na segunda metade do século XX: um balanço crítico. 2003. Doctoral Thesis, Instituto de Economia Campinas da Universidade Estadual de Campinas, 2003.

ALENCAR, A. A; GOBETTI, S. W. Justiça Fiscal na Federação Brasileira: uma análise do sistema de transferências intergovernamentais entre 2000 e 2007. Finanças Públicas - XIII Prêmio Tesouro Nacional, 2008.

ALLEN, F; QIAN, J; ZHANG, C; ZHAO, M. Chinas financial system: opportunities and challenges in FAN, J; Morck, R. (Eds). Capitalizing China, University of Chicago Press (forthcoming).

BAHL, R; WALLACE, S. Public financing in developing and transition countries public Budgeting E Finance. v. 25, n. 4, p. 83-98, 2005.

BECKET-CAMARATA, J. The current impact of the tightening credit market on municipal borrowing costs: a case study. Municipal Finance Journal. v. 29, n. 4, p. 77-86, 2009.

BERNANKE, B. S. Challenges for state and local governments. Address. 2011 Annual Awards Dinner of the Citizens Budget Commission, New York, 2 March 2011.

BLANCHARD, O. J. Fiscal dominance and inflation targeting: lessons from Brazil. MIT Department of Economics Working Paper No. 04-13, 2004.

BREMAEKER, F. E. J; Panorama das finanças municipais em 2005. Instituto Brasileiro de Administração Municipal, Rio de Janeiro, RJ: October 2006

BRESSER-PEREIRA, L. C; GALA, P; Por que a Poupança Externa não Promove Crescimento. Revista de Economia Política, vol. 27, n 1, p. 3-19, 2007.

CARVAlHO, C; PUTOMATTI, G; REI$\mathrm{NACH}, \mathrm{S}$. Sustentabilidade do endividamento dos governos subnacionais: BIRD x Caso brasileiro. Presentation, FGV-EAESP, March, 2012.

CENTRAL BANK OF BRAZIL. Departamento da Dívida Pública, Programa de Refinanciamento das Dívidas Públicas Municipais Relatório das Operações Realizadas. (Resolução no 37, de 17/09/1999, do Senado Federal - art. 4º). Brasília, DF: 2000.

CONFEDERAÇÃO NACIONAL DE MUNICÍPIOS. Uma Proposta para Avaliar a Gestão das Prefeituras: O Índice de Responsabilidade Fiscal, de Gestão e Social dos Municípios. Brasília, DF: 2006 
EATON, K; DICKOVICK, J.T. The politics of recentralization in Argentina and Brazil. Latin American Research Review, v. 39, n. 1, p. 90-122, 2004.

FELDSTEIN, S.G; FABOZZI, F.J (eds). The Handbook of Municipal Bonds. Hoboken, NJ: Wiley \& Sons, 2008.

FRANDT, H. High Powered and low-powered incentives in the public sector. Journal of Public Administration Research and Theory. v. 6, n. 3, p. 365-81, 1996.

FSOC, FINANCIAL STABILITY OVERSIGHT COUNCIL. Annual Report. Washington, DC. 2011.

GAO, GOVERNMENT ACCOUNTING OFFICE. Dodd-Frank Wall Street reform act: role of the governmental accounting standards board in the municipal securities markets and its past funding. Washington, DC: GAO, 2011.

GASB, GOVERNMENT ACCOUNTING STANDARDS BOARD. State and local government use of generally accepted accounting principles for general purpose external financial Reporting. Norwalk, CT: GASB, 2008.

GASPARINI, C.E; MIRANDA, R.B. Evolução dos aspectos legais e dos montantes de transferências realizadas pelo fundo de participação dos municípios. Brasília: Ipea, Texto para Discussão, n. 1.243, 2006.

GIAMBIAGI, F; BLANCO, F; ARDEO, V. Proposta de recriação de uma dívida estadual e municipal com o setor financeiro privado. Revista do BNDES. v. 14, n. 29, p. 365-98, 2008.

HAGOPIAN, F. Traditional Politics and Regime Change in Brazil. Cambridge: Cambridge University Press, 2007.
HILDRETH, W.B; ZORN, C.K. The evolution of the state and local government municipal debt market over the past quarter century. Public Budgeting E Finance. v. 25, n. 4, p. 127-61, 2005.

KATZMAN, M.T. Municipal bond banking: the diffusion of a public-finance innovation. National Tax Journal. v. 33, n. 2, p. 149-60, 1980.

LAMB, R; Leigland, J; Rappaport, S. (eds). The Handbook of Municipal Bonds and Public Finance. New York: New York Institute of Finance, 1993

LEVINE, S. Presentation Municipal Finance Development Seminar, FGV-EAESP, 2009

MAGRASSI, M. Sub-national investment needs and financial market response sector study. Washington D.C: Inter-American Development Bank, 2000 .

MARTELL, C. R; GUESS, G. M. Development of local government debt financing markets: application of a market-based framework. Public Budgeting and Finance. v. 26, n. 1, p. 88-119, 2006.

MAURO, P; SUSSMAN, N; YAFEH, Y. Emerging Markets and Financial Globalization: Sovereign Bond Spreads in 1870-1913 and Today. Oxford: Oxford University Press, 2006

MENDES, M; MIRANDA, R. B; COSIO, F. B. Transferências intergovernamentais no brasil: diagnóstico e propostas de reforma. Brasília: Consultoria Legislativa do Senado Federal, (Textos para Discussão, n. 40), 2008.

OLENSCKI, A.R.B. Modelo Brasileiro de Crédito Municipal (2000 a 2006): uma análise de controles governamentais e características da oferta.
2008. Doctoral Dissertation, Escola de Administração de Empresas da Fundação Getulio Vargas, São Paulo, 2008

PETERSEN, G; Municipal Funding Arrangements: global experience and lessons learned. International Workshop on Strengthening Local Infrastructure Financing. Dambulla: Asian Development Bank, 2006.

PETERSEN, G; Building Local Credit Systems. Washington D.C: World Bank, 1997.

REZENDE, F. Conflitos Federativos e Reforma Tributária. Presentation to Brazilian Treasury Seminar on Public Finance, 2006.

RODRICK, D. (ed). In Search of Prosperity: Analytic Narratives on Economic Growth. Princeton: Princeton University Press, 2003

SANO, H; ABRUCIO, F. L. Promessas e resultados da Nova Gestão Pública no Brasil: o caso das organizações sociais de saúde em São Paulo. RAE-Revista de Administração de Empresas, v. 48, n. 3, p. 64-80, 2008.

SECRETARIA DO TESOURO NACIONAL. Operações de Crédito de Estados e Municípios, Manual de Instrução de Pleitos. Brasília, DF: 2006.

STARNER, F.L. General Obligation Bond Financing by Local Governments: A Survey of State Controls. Berkeley: University of California Press, 1961.

WILLIAMSON, O. Public and private bureaucracies: a transactions cost economics assessment. Washington: Institute for Policy Reform, Working Paper IPR84, 1994. 